\title{
Lobbies: Another Dose for Protectionism
}

\author{
Montej Abida ${ }^{1}$ \\ ${ }^{1}$ School of Business, University of Sfax, Tunisia \\ Correspondence: Montej Abida, School of Business, University of Sfax, BP 1081 Sfax 3018, Tunisia. Tel: \\ 216-98-487-913. E-mail: montejabida@gmail.com
}

\author{
Received: May 22, 2013 \\ doi:10.5539/ijef.v5n8p121 \\ Accepted: June 27, $2013 \quad$ Online Published: July 26, 2013 \\ URL: http://dx.doi.org/10.5539/ijef.v5n8p121
}

\begin{abstract}
The objective of this paper is to examine the influence of lobbies on the choice of a country's trade policy. The existence of several illegal financings of electoral campaigns has led us to ask questions about the proliferation of protectionist trade practices. Indeed, there are sources of illegal financing such as bribes for granting a commitment to a tariff protection of a lobby's interests.

A new conception attempts to show that the political players are the main responsible for the adoption of a protectionist trade policy: the political players, who are financed by companies during their electoral campaigns, should keep their promises vis-à-vis these companies by raising excise duties or adopting unfair trade policies such as export subsidies.

Lobbying is able to disrupt international trade negotiations by exerting pressure on its government and obliging it to take a decision that does not comply with the rules of international trade. International trade negotiations taking place within the GATT are often disturbed by political issues: the political and social pressures have continued ravaging the international trade negotiations. The best known example is the problem of agricultural subsidies between the EU and the United States.

To solve the problems related the control of political spending, we assumed the existence of a monitoring body that is called (ICCERGI) (Independent Commission for the Control of Elections and Research of General Interest) which plays the role of "Principal". The aim of the latter is to control the operations that take place between political parties and interest groups, that we called the "Agents".
\end{abstract}

Keywords: lobbying, political parties, election campaigns, protectionism, WTO, Principal-Agent model

\section{Introduction}

In this paper, we are going to develop a model that explains the effect of the political process on the determination of trade policy. Political issues have a great influence on the choice of the business strategy that the government has to follow. A new conception attempts to show that the political players are the main responsible for the adoption of a protectionist trade policy: the political players, who are financed by lobbies (or interest groups or pressure groups) during their election campaigns, must keep their promises vis-à-vis these lobbies by raising customs duties or adopting unfair trade policies such as export subsidies.

There are several kinds of lobbies which exert pressure on the government (Libaert and Bardon, 2012). The question is: who are really these lobbyists and how do they influence public decisions (Daridan and Luneau, 2012). Among these lobbies there are the trade unions, religious groups and associations that deal with, for example, environmental issues, poverty and exclusion. Brugvin (2009) adds other types of lobby such as the numerous research offices, consulting firms, public-relation as well as public- affair agencies. According to this author, professional associations contribute to the development of international policies. Similarly, Koutroubas and Lits (2011) show that many pressure groups have professionalized their contracts with policy-makers and interfere with the political choice processes.

Indeed, several models are interested in analyzing the interaction between economic and social interests which are often represented by "lobbyists" and the particular interests of the political players. Among the authors who have invested in this area, we can state Brock and Magee (1978), Findlay and Wellisz (1982), Feenstra and Bhagwati (1982). " Instead of a benevolent government, we must model rational politicians eager to maximize a certain objective function with election-like elements, reelection or other more direct gains" (Laussel and Montet, 
1994). Similarly, Guillochon (2006) showed that a country's protection degree depends mainly on pressures exerted by the producers on political bodies either by votes or by lobbying.

There is a strong relationship between the political parties and the lobbies. We often refer to a pressure group belonging to a political party. For example, in France, the GCL (General Confederation of Labour) is a very close union to the Communist Party. In contrast, the CNPF (National Confederation of French Employers) is a traditionally sympathizing union of right-wing parties. As the election campaigns of politicians are funded, in part, by companies, it is then obvious that the political players, in their turn, defend these companies when they are in difficulty.

Our model examines the interactions between the interests of political players and those of pressure groups, we are going to study the interactions between the political players seeking to influence the public opinion by adopting protectionist trade policies. The political players who are supported by some companies during their election campaigns, are forced to defend the economic interests of these companies. This obligation may disrupt the international trade negotiations because we can not talk about free trade by following purely protectionist strategies. The political climate of a country may be responsible for the success or failure of international trade negotiations.

The trade negotiations of the Uruguay Round have demonstrated the existence of political pressure when the government in power wants to take a decision on any business problem. Lobbies have their say in the business strategy that the government will follow in international trade negotiations. This is the case of the French farmers in the Euro-American conflict over export subsidies, for example. The International trade negotiations of the Uruguay Round have been influenced by the protests of the French pressure groups that wanted at any cost to protect the interests of their farmers.

The Common Agricultural Policy (CAP) represents about $40 \%$ of the European Union budget. The agricultural conflict between the European Union and the United States has shown the influence degree of lobbies on the progress of the Uruguay Round trade negotiations. It should be noted that trade in agricultural products is largely dominated by the European Union and the United States. Indeed, in 2010, according to the World Trade Organization (WTO), the European Union represented 9.5\% of the world exports in agricultural products. During the same year, the United States share is $10.1 \%$.

The agricultural problem between the European Union and the United States is based mainly on production aid. Indeed, the production subsidy is the most important strategy of the CAP, "the aid per hectare or head of livestock for producers to compensate for the reduction in agricultural prices to make them closer to world prices" (CAP 2013 Group, page 23). Through rounds of negotiations, the WTO is seeking solutions to the problem of agricultural subsidies by asking the European Union to review of the CAP in a more liberal direction (European Council for Agricultural Law, 2011).

This article will analyze the importance of lobbying in the choice of the country's trade policy: the lobby discusses major economic and strategic issues facing the country. It now seems difficult to analyze the issues of international trade without taking into account explicitly the influence of interest groups and the political players in each country. The government, the opposition players and the lobby groups are the main players. We will show that lobbies that participate greatly in the adoption of a protectionist trade policy. Under the direct or indirect influence of the lobby, the policymaker must consider this pressure when he has to make a decision about a business problem negotiated world wide.

Because the real reason for the pressure of the lobby is not perfectly observable, we assumed that the existence of a committee called "Independent Commission for the Control of Elections and Research of General Interest (ICCERGI)". The commission's task is to control illegal practices used by the lobbies and the political parties during the election campaign. We used the Principal-Agent model to avoid the interference of the lobby in the political game. The objective of (ICCERGI), which plays the role of "Principal" is to create an incentive mechanism able to solve primarily the problem of asymmetric information and to control, on the other hand, the operations that take place between the political parties and the lobbies (the latter play the role of "Agents").

\section{The Importance of the Lobby}

The lobby plays an important role in the choice of trade policy. According to Polere (2007), lobbying has been booming in France and in Europe since the mid-1990s, mainly because of the European integration and the evolution of society and types of governance. Interest groups can potentially influence the policy makers by providing contributions and relevant information to sway the decision in favor of the group (Bennedsena and Feldmann 2006). Brugvin (2009) analyzes the different political and economic types of lobby which are 
undemocratic, unequal and illegal.

Unlike the existing system in the United States, Debouzy (2003) argues that lobbying in France is, by definition, a "discrete, obscure and underground" activity. According to Garault and Fretwell (2012), lobbying in France is poorly defined and misunderstood. Lobbying often remains seen as an element which negatively affects that decision. However, lobbying is an important contribution of civil society to the development of law if it is based on expertise in accordance with the rules of transparency and ethics. The negative face attributed to lobbying in France is put into question to discover the benefits of this practice (and Libaert Bardon, 2012).

\section{The Terms of Election Campaign Financing}

For most countries, the campaign is funded in two ways: a public funding and a private one. The problem that always arises is in private funding. Indeed, there are several illegal private financings of election campaigns. For example, during the French 2007 presidential election, the candidate Sarkozy is suspected of illegally financing his election campaign. Normally, the funding sources of political parties come from contributions and private individuals.

According to the French law, each candidate must meet three requirements. The first is holding a campaign account that sets very precisely the origin of income and the nature of the expenditure. Since the Organic Law of 05 April 2006, the account must be submitted to the National Commission of Audit and Financial Policies (NCAFP) not later than the ninth Friday after the second round of voting in order to check the regularity. The second rule is related to setting spending limits the amount of which rose in 2007 to 16,160,000 Euros for the candidates in the first round and to 21.59 million for those in the second round. Reimbursement of campaign expenses is expected. The third rule is to limit donations from private persons to 4600 Euros. Any donation less than 150 Euros cannot be made in cash. In 1995, donations from private companies were banned.

For example, during the U.S. presidential campaign in 2012, the candidate Barack Obama and Mitt Romney, spent about six billion dollars. This campaign is the most expensive in the history of the United States. Indeed, the "Super PAC: Political Action Committee," (political action committees of both parties) allowed both candidates to circumvent the laws of finance.

\section{The Politico-Commercial Model as a Principal-Agent Model}

The theory of contracts and that of incentives highly take a great part in the resolution of agency problems. Indeed, in these recent decades, the economic analysis of the contract theory has been highly developed. It has been applied in many fields such as finance, the labor market, the insurance industry, Salanié (1994) presented the basic models of contract theory by analyzing three main models that are based on self-selection, signals and moral hazard.

The principal-agent model is developed by the agency theory. Indeed, the general shape of the agency relationship is defined as "a contract by which one or more people (the principal) engage another person (the agent) to perform an action on their behalf, which implies giving the delegation to an agent to take certain decisions " (Jensen and Meckling 1976, p. 313).

The existence of a conflict of interest between the principal and agents has greatly led many economists to consider this problem. Indeed, the presence of information asymmetry is at the basis of the existence of conflicting interests between the principal and agents. The asymmetric information problems come in two forms depending on the nature of the information: the first form is related to the adverse or adverse selection and the second one illustrates the problem of moral hazard or risk.

The anti-selection problem is based on uncertainty about the type of agent: during the signature of the contract, the principal does not know the hidden information by the agent. Therefore, the agent conceals private information about an exogenous variable. On the contrary, the problem of moral hazard is a situation of hidden action after the signature of the contract: it is the behavior of the agent which is unknown. Thus, the Principal does not observe the action of the agent that is an endogenous variable. The principal-agent models can unify between the case of adverse selection and the moral hazard: the Principal has no idea about the exogenous and endogenous variables.

Laffont and Martimort (2002) presented a more detailed introduction on the theory of incentives through the analysis of principal-agent models. Indeed, these two provided the methodological tools to set up institutions that can assure the right incentives for economic agents. According to Laffont $(1993,2006)$, the incentive theory studies "the development of rules and institutions that encourage economic agents to make great efforts to transmit correctly any private information that is socially relevant" (Laffont (2006), p.177). 
In our model, the role of the "Principal" can not be detained by any political player. Indeed, we have seen that the political player and the lobbies get on well with each other. We will then assume, in the manner envisioned by the auctioneer Walras, the existence of a player who is looking for the public interest. So, we call it "Independent Commission for the Control of Elections and Research of General Interest (ICCERGI)" the" Principal " in this game and the political parties and lobbies," Peripheral Agents". The ideal is to find a body that can remove lobbies from the political game. The supervisory body must control the illegal operations well by prohibiting the lobby from making deals with the political players. The supervisory body should be honest and should not interfere in the political game.

It is possible to admit that the "ICCERGI" can create an incentive mechanism to prevent the lobby from intervening in the political game. The elimination of high pressure on the "ICCERGI" makes the political game much more transparent. The lobby should just deal with the legal protection of the interests of its companies and must move away from politics by not doing business illegally. Our goal is to make the lobby get away from politics.

The "ICCERGI" should encourage the lobby to reveal its private information. It must try to protect the economic interests of all domestic firms so that some lobbies do not exert pressure. Seeking the public interest is a top priority that "ICCERGI" must achieve. Without this goal, "ICCERGI" cannot induce the lobby not to participate in politics. The "ICCERGI" should encourage the lobby to cooperate and look for the welfare of the whole country.

We assume that the "ICCERGI" has the power to prohibit the lobby to intervene in the political game. The "ICCERGI" should set the rules that apply to each lobby (where there is a constraint in participation). For the interests of the country, there is no point in changing the rules which are the same for all exogenous signals.

\subsection{The Information Structure}

The lack of visibility on the real reason for the funding of a political party shows that there is a hidden information held by lobbies. Similarly, the intensity of the pressure that lobbies exert on the player in power is often exaggerated: the information about the real reason for the protests of lobbies is certainly misleading. It is not clear whether the lobby defends only the economic interests of some people or he is also involved in the political issues. The existence of pressure groups in favor of the political parties plays an important role in the intensity of the pressure exerted on the player in power. So, ignorance of the true characteristic of the relationship between lobbies and political parties obliges us to find a mechanism capable of encouraging the lobby to reveal the true characteristic of this relationship.

\subsubsection{Pressure Groups Transmit Information}

The reaction of lobbies against any decision of the player in power plays an important role in the transmission of information (This idea has been developed by Mayer 1993 Reizman and Wilson 1993). Indeed, if we take the example of international trade issues, we notice clearly that the lobbies' protests give us an idea of the international trade environment and more exactly the atmosphere of international trade negotiations. The lobbies, therefore, help us find out the strategies and trade policies used by each country.

The lobbies also give us information on trade policy that the player in power will follow during international trade negotiations. By their aggressive methods and events that they organize, lobbies make the public aware of what is happening in international trade negotiations. The violent protests of French farmers against their government helped the public to be close in following the outcome of trade negotiations of the Uruguay Round, especially the agricultural problem that happened between the European Union and the United States. So, the lobbies transmit information, even if it is often amplified.

\subsubsection{The Existence of Asymmetric Information}

Information play an important role in the politico-commercial game. Thus, the existence of information asymmetry between the "ICCERGI" and the political parties and lobbies leads us to use the theory of incentives in order to encourage lobbyists to disclose accurate information concerning the real reason for financing political parties. The "ICCERGI" must also know the main cause of discontent among lobbies towards any commercial problem. Indeed, lobbies can be influenced by the players in opposition who try to sabotage only the player in power and do not try to find the best solution to the commercial problem at hand. The principle of "give and take" that exists between political players and lobbies is the first source of information asymmetry.

\subsubsection{The Influence of Asymmetric Information on the Choice of Trade Policy}

Information asymmetries between the player in power and lobbies are a systematic source of inefficiency in the 
choice of trade policy. If the lobbies are excluded from the political game, we are certain that the player in power can choose a decision that protects the public interest and not the interest of individuals. Lobbies exploit political players at the expense of the economic efficiency of a country in particular, and free trade in general. The player in power may not be able to negotiate appropriately with other countries as long us there is a strong pressure on him.

The Information about the real reason for the pressure of the lobby is very important in the game of international trade negotiations. Indeed, the lobby is a threat to the game of free trade. The pressure of the lobby on the player in power can disrupt international trade negotiations and create a non-cooperative environment worldwide.

\subsubsection{Lobbies Have Private Information}

In the politico-commercial game, they are lobbies that are responsible for the existence of information asymmetries. Indeed, the pressure exerted by the lobby on the player in power is often exaggerated only the lobbies can get along with the players in the opposition to sabotage the player in power. This asymmetric information and strategic behavior of political players and lobbies are the main problems that the "ICCERGI" has to resolve.

The atmosphere of the politico-economic game depends on the private information held by the lobbies. This information is not observable by the "ICCERGI" because it is costly for lobbies. These latter are still trying to deny the existence of an agreement between them and the political players. They are especially the lobbies that have not helped the player in power during his election campaign that will hold this private information. As a precaution, each lobby prefers to keep the agreement secret between them and the political players. The "ICCERGI" cannot perfectly observe the strategy of lobbies. They have an advantage in terms of information about the pressure they exert on the player in power.

Thus, we assume that trade policies depend on the information $\theta$ that lobbies transmit $(\theta \in \theta)$. The exact value of $\theta$ is a private information of $L$ (Lobbies). The variable $\theta$ represents the actions of lobbyists when they knew the decision of the "ICCERGI". For example, if the player in power can choose a commercial policy of free trade, the lobby representing farmers will protest and demand that the player in power can follow a protectionist trade policy. So, the action of the lobby depends on the decision that the player in power will be able to take on any business problem. Thus, regardless of the decision that the player in power will take, there will always be a reaction of the lobbies since these latter are numerous and represent a number of activities that do not have the same objectives.

\subsection{The Principal Is Represented by "ICCERGI" and the Lobbies Are Represented by Agents}

The goal of "ICCERGI" is to encourage the lobby to reveal accurate information about the pressure it exerts. To achieve this goal, we will use a model of principal-agent which consists in considering the "ICCERGI" as the Principal and lobbies as Agents. The Principal-Agent models can be useful for us in the resolution of conflicts arising between "ICCERGI" and lobbies. For the "ICCERGI" there is ignorance of the characteristics of the pressure exerted by the lobby. The lack of observation of the true reason for of this pressure led the "ICCERGI" to find a mechanism that reveals the private information.

\subsubsection{The Politico-Commercial Game Is a Model of an Adverse Selection-Type}

The lobby has private information about the true reason for the pressure it exerts. This case shows that the lobby has an informational rent. The "ICCERGI" should create a mechanism of self-selection so that the announcement of the real reason for the pressure should be advantageous to the lobby. This mechanism is to protect the economic interests of the whole country, while maintaining good relations with other countries participating in the game of international trade. When "ICCERGI" proves that seeks to protect the interests of the lobby, the latter will have no reason to intervene in the political game.

Ensuring adequate protection of the interests of domestic enterprises must eliminate any agreement between the lobby and the political players. Thus, the "ICCERGI" has every opportunity to get the lobby away from politics. The lobby has no interest in meddling in the affairs of political players. It must deal with the protection of the economic interests of domestic firms by using legal means.

In this model, we will assume that the "ICCERGI" as the Principal and lobbies as peripheral Agents identified by $(\mathrm{i}=1, \ldots, \mathrm{n})$. We call $\theta$ the variable of adverse selection, which represents the characteristic of the lobby. This characteristic is based on the amplitude of the pressure of the lobby on the player in power.

$$
\theta=\left[\theta_{1}, \ldots, \theta_{i}, \ldots, \theta_{n}\right] ; \theta \in \theta
$$


$\theta$ : vector called profile of the characteristics of the lobby.

$\theta:$ set of the characteristics of lobbies.

$$
\theta=\prod_{i=1}^{n} \theta_{i}
$$

So, each lobby "i" has private information $\theta_{i} \in \theta_{i}$, which represents the real reason for the pressure it exerts on the player in power. $\theta$ segment belonging to a convex set: $[\underline{\theta}, \bar{\theta}] \subset \Re$. Each lobby knows its own characteristic, the "ICCERGI" does not know it.

\subsubsection{Creating a Revealing Mechanism}

When the player in power participates in international trade negotiations of the WTO, he should expect pressure from the contracting parties. This pressure will be accompanied by the pressure of the lobby $(\mathbf{L})$ which is often exaggerated. For this, the "ICCERGI" must impose a mechanism $\left(g(),. M_{1}, \ldots . ., M_{n}\right)$ which consists of a space of messages $M_{i}$ for each lobby "i" and a function $g($.$) de M_{1} \times \ldots . . \times M_{n}$ in the space of allocations.

The function $g()=.\left(g_{1}(),. \ldots \ldots, g_{n}().\right)$ determines the allocations of $\mathbf{n}$ lobbies based on the messages they had sent. At the equilibrium of this game, the lobby "i" chooses a message $m_{i}{ }_{i}$ in $M$ and sends it to "ICCERGI" which then imposes the allocation $g\left(m_{1}^{*}, \ldots, m_{n}^{*}\right)$.

The player will be able to pursue international trade negotiations based on the message $m_{i}{ }_{i}$ of the lobby. Thereafter, we will assume the existence of a single agricultural lobby $\left(L_{1}\right)$. So we have $\mathrm{n}=1$.

Considering the mechanism $(g(), M$.$) , the agricultural lobby chooses its announcement in order to maximize its$ usefulness $u(g, \theta)$ :

So he gets the allocation:

$$
m^{*}(\theta) \in \arg \max u(g(m), \theta)
$$

$$
g *(\theta)=g\left(m^{*}(\theta)\right)
$$

The revelation principle shows that we may be limited to direct and revealing mechanisms. It is in the interest of agricultural lobby to reveal the real reason for the pressure it exerts on the player in power. So you have the messages sent by the agricultural lobby have to coincide with its features. The announcement of the real reason for the pressure is an optimal strategy.

The allocation $g^{*}(\theta)$ can be implemented by protecting the economic interests of the agricultural lobby. This latter should no longer participate in politics since the "ICCERGI" will make a decision that maximizes the welfare of the whole country. The revealing mechanism should encourage the agricultural lobby to reveal the real reason for the pressure it exerts on the "ICCERGI".

If the mechanism that "ICCERGI" has created is not revealing, then the agricultural lobby of the characteristic $\theta$ would take advantage of lying by announcing $\theta^{\prime}$ that does not match with the real $\theta$ characteristic and thus we would have this:

$$
u\left(g^{*}(\theta), \theta\right)<u\left(g^{*}\left(\theta^{\prime}\right), \theta\right)
$$

We are going now to assume that the preferences of "ICCERGI" are represented by a weighted sum of welfare, which in this case is the sum of surplus of producers and consumers. 


\subsubsection{The Consumer Surplus}

We assume that the quantity q can take any value in $\mathfrak{R}^{+}$, and that the price $P(q)$ that the consumer is ready to pay is a function which is continuous and decreasing. The total value for the consumer of a quantity $\mathbf{q}$ is the area under the curve of demand, given by:

$$
z(q)=\int_{0}^{q} P(\widetilde{q}) d \widetilde{q}
$$

We assume that the subsidies granted to farmers are financed by the tax receipts collected by the government. Although the value of Taxes (T) paid by the consumers equals that of the subsidy (S). Then we consider that if the consumers do not pay these taxes, the French farmers can not benefit from subsidies. However, the consumers prefer not to give taxes to increase their surplus.

Consumer surplus can be written as follows:

$$
K=\int_{0}^{q} P(\widetilde{q}) d \widetilde{q}-T
$$

By replacing $\left(\int_{0}^{q} P(\widetilde{q}) d \widetilde{q}\right)$ by $z(q)$ and $T$ by $S$, the value of the surplus then becomes:

\subsubsection{The "Principal" Preferences}

$$
K=z(q)-S
$$

Thus, when the "ICCERGI" pays attention to consumers through the import of foreign goods and wants to avoid a trade war with the other countries, it will indirectly provide more gains to foreign producers.

$$
W=K+\alpha \Pi^{N}
$$

With: - W: Welfare of the whole country.

- K: National consumer surplus.

$-\pi^{N}$ : Profit of the domestic producer. The value of $\pi^{N}$ gives us an idea about the atmosphere of the negotiations within the country. That is to say, it indicates the degree of pressure exerted by the lobby on the player in power.

We assume that: $\pi^{N}=B-C=R+S-C$

With: S: Subsidy awarded to French farmers.

B: Revenue of the domestic producer which is equal to the revenue (R) and the subsidy (S).

C: Cost of domestic producer.

Since: $\mathbf{K}=\mathbf{z}(\mathbf{q})-\mathbf{S}$, then the function of welfare becomes:

$$
\mathbf{W}=\mathbf{z}(\mathbf{q})-\mathbf{S}+\boldsymbol{\alpha}(\mathbf{R}+\mathbf{S}-\mathbf{C})
$$

If $\mathbf{0}<\boldsymbol{\alpha}<\mathbf{1}$ : selected by "ICCERGI" and represents the weighting it gives to each profit monetary unit of the domestic producer.

(2) If $\boldsymbol{\alpha}=\mathbf{1}$ : we pay as much importance to a national monetary unit of a local producer as to the consumer. This case eliminates the subsidy that "ICCERGI" gives to its farmers $(\mathbf{W}=\mathbf{z}(\mathbf{q})+\mathbf{R}-\mathbf{C})$. The Contracting Parties to the WTO prefer this case because it complies with the rules of free trade.

(3) If $\boldsymbol{\alpha}$ decreases: it gives more importance to the domestic producer $\left(\boldsymbol{\pi}^{\mathbf{N}}=\frac{\mathbf{1}}{\boldsymbol{\alpha}}(\mathbf{w}-\mathbf{K})\right.$, so $\mathbf{R}$ increases when $\boldsymbol{\alpha}$ decreases). The pressure groups adopting a protectionist policy always try to approach this situation in order to protect the interests of domestic producers. The candidate for an election, who devotes a great importance to financing his election campaign, ensures that $\boldsymbol{\alpha}$ is as small as possible.

(4) If $\boldsymbol{\alpha}$ grows, it gives more importance to the consumer. The Contracting Parties to the WTO like this situation a lot.

Every candidate for election will play on $\boldsymbol{\alpha}$ in international trade negotiations. Indeed, if he wants to get funds for his election campaign, he must ensure that the maximum $\boldsymbol{\alpha}$ decreases, even if the tension increases in international trade negotiations.

Thus, "ICCERGI" preferences depend on the profit of the domestic producer $\left(\pi^{N}\right)$, the consumer surplus (K) 
and the subsidy (S) that will be offered to the domestic producer.

$$
W^{G} \equiv W\left(K, \pi^{N}, S\right)=z(q)-S(\theta)+\alpha \pi^{N}(\theta)
$$

\subsection{The resolution of Political and Commercial Model}

The "ICCERGI" will maximize the expectancy of social surplus under the two incentive constraints and participation that we will analyze in the following section.

4.3.1 The Incentive Constraints

We will assume that the preferences of the lobby depend on its income $(\mathbf{B})$, cost of production $(\mathbf{C})$ and its characteristic $\theta$.

$$
\mathbf{U}^{\mathrm{L}} \equiv \mathrm{U}(\mathrm{B}, \mathrm{C}, \boldsymbol{\theta})=\mathbf{R}(\boldsymbol{\theta})+\mathrm{S}(\boldsymbol{\theta})-\mathrm{C}(\boldsymbol{\theta})
$$

The agricultural lobby chooses $(\mathbf{B}(\boldsymbol{\theta}), \mathbf{C}(\boldsymbol{\theta}))$ which is assigned by the "ICCERGI". We suppose that $\mathbf{U}^{\mathbf{L}}(\boldsymbol{\theta}, \hat{\boldsymbol{\theta}})$ the obtained utility by the agricultural lobby of $\theta$ characteristic which states that its characteristic is $\hat{\boldsymbol{\theta}}$ and then receives the utility:

$$
\mathbf{U}^{\mathrm{L}}(\boldsymbol{\theta}, \hat{\boldsymbol{\theta}})=\mathrm{U}(\mathbf{B}(\hat{\boldsymbol{\theta}}), \mathrm{C}(\hat{\boldsymbol{\theta}}), \boldsymbol{\theta})
$$

The mechanism $(\mathbf{B}, \mathbf{C})$ checks the incentive constraint if and only if:

$$
\text { (IC) } \quad \mathbf{U}^{\mathrm{L}}(\boldsymbol{\theta}, \boldsymbol{\theta}) \geq \mathbf{U}^{\mathrm{L}}(\boldsymbol{\theta}, \hat{\boldsymbol{\theta}}), \quad \forall \boldsymbol{\theta} \in \boldsymbol{\theta} \quad \text { and } \quad \forall \hat{\boldsymbol{\theta}} \in \boldsymbol{\theta}
$$

We assume that the utility of this lobby takes the following form:

$$
U(B, C, \theta)=u(B, \theta)-C
$$

For the $(\mathbf{B}, \mathbf{C})$ to be compatible with the incentive constraint, we must, by the conditions of the first and second order, that:

$$
\forall \boldsymbol{\theta} \in \boldsymbol{\theta}, \quad \frac{\partial \mathbf{U}^{\mathbf{L}}}{\partial \hat{\boldsymbol{\theta}}}(\boldsymbol{\theta}, \boldsymbol{\theta})=\mathbf{0}
$$

And

$$
\forall \boldsymbol{\theta} \in \boldsymbol{\theta}, \quad \frac{\partial^{2} \mathbf{U}^{\mathrm{L}}}{\partial \hat{\boldsymbol{\theta}}^{2}}(\boldsymbol{\theta}, \boldsymbol{\theta}) \leq \mathbf{0}
$$

The first order condition is:

$$
\frac{d C}{d \theta}(\theta)=\frac{\partial u}{\partial B}(B(\theta), \theta) \frac{d B}{d \theta}(\theta)
$$

The second order condition is:

$$
\frac{d^{2} C}{d \theta}(\theta) \geq \frac{\partial^{2} u}{\partial B}(B(\theta), \theta)\left(\frac{d B}{d \theta}(\theta)\right)^{2}+\frac{\partial u}{\partial B}(B(\theta), \theta) \frac{d^{2} B}{d \theta^{2}}(\theta)
$$

We can simplify the second order condition by deriving (18):

$$
\int \frac{\mathbf{d}^{2} C}{d \theta^{2}}(\theta)=\frac{\partial^{2}}{\partial B^{2}}(B(\theta), \theta)\left(\frac{d B}{d \theta}(\theta)\right)^{2}+\frac{\partial^{2} u}{\partial B \partial \theta}(B(\theta), \theta) \frac{d B}{d \theta}(\theta)+\frac{\partial u}{\partial B}(B(\theta), \theta) \frac{d^{2} B}{d \theta^{2}}(\theta)
$$

By substituting in (9), we obtain: 


$$
\frac{\partial^{2} u}{\partial B \partial \theta}(B(\theta), \theta) \frac{d B}{d \theta}(\theta) \geq 0
$$

For simplicity, we will use the Spence-Mirrlees condition by assuming that $\left(\frac{\partial^{2} \mathbf{u}}{\partial \mathbf{B} \partial \theta}\right)$ keeps a constant sign

$\forall \boldsymbol{\theta} \in \boldsymbol{\theta}$. We will continue the calculations by assuming that this derivative is positive:

$$
\left.\forall \boldsymbol{\theta}, \forall \mathbf{B}, \frac{\partial^{2} \mathbf{u}}{\partial \mathbf{B} \partial \boldsymbol{\theta}}(\mathbf{B}, \boldsymbol{\theta})\right\rangle \mathbf{0}
$$

The political and commercial significance that we have adapted to the condition of Spence-Mirrlees is that the lobbies of $\boldsymbol{\theta}$ with higher characteristic are ready to leave the political game more than the low $\boldsymbol{\theta}$ for an additional unit of income $\mathbf{B}$ or more exactly for an additional unit of subsidy $\mathbf{S}$. The "ICCERGI" can therefore separate lobbies by offering incomes $\mathbf{B}$ (that is to say subsidies $\mathbf{S}$ ) higher to the high $\boldsymbol{\theta}$. The Spence-Mirrlees condition gives us a clear idea about the characteristics of lobbies. That is to say, this condition allows us to make a selection of different types of lobby.

We can show that $\mathbf{B}$ is part of a direct revealing mechanism (B,C) if and only if the income $\mathbf{B}$ is increasing.

$$
\frac{\partial \mathbf{U}^{L}}{\partial \hat{\theta}}(\boldsymbol{\theta}, \hat{\boldsymbol{\theta}})=\frac{\partial \mathbf{u}}{\partial B}(\mathbf{B}(\hat{\theta}), \boldsymbol{\theta}) \frac{\mathbf{d B}}{\mathbf{d \theta}}(\hat{\boldsymbol{\theta}})-\frac{\mathbf{d C}}{\mathbf{d \theta}}(\hat{\theta})
$$

By writing the equation (18) into $\hat{\boldsymbol{\theta}}$, we obtain:

$$
\frac{\partial u}{\partial B}(B(\hat{\theta}), \hat{\theta}) \frac{d B}{d \theta}(\hat{\theta})=\frac{d C}{d \theta}(\hat{\theta})
$$

We then obtain:

$$
\frac{\partial U^{L}}{\partial \hat{\theta}}(\theta, \hat{\theta})=\left(\frac{\partial u}{\partial B}(B(\hat{\theta}), \theta)-\frac{\partial u}{\partial B}(B(\hat{\theta}), \hat{\theta})\right) \frac{d B}{d \theta}(\hat{\theta})
$$

But with the Spence-Mirrlees condition, the sign of the term on the right is that $\frac{\partial^{2} \mathbf{u}}{\partial \mathbf{B} \partial \boldsymbol{\theta}}(\mathbf{B}(\hat{\boldsymbol{\theta}}), \boldsymbol{\theta} *)(\boldsymbol{\theta}-\hat{\boldsymbol{\theta}}) \frac{\mathbf{d B}}{\mathbf{d} \boldsymbol{\theta}}(\hat{\theta})$ for $\boldsymbol{\theta} *$ between $\boldsymbol{\theta}$ and $\hat{\boldsymbol{\theta}}$. This term has the sign of $(\boldsymbol{\theta}-\hat{\boldsymbol{\theta}})$, from the equation (19). The function $\hat{\boldsymbol{\theta}} \longrightarrow \mathbf{U}^{\mathbf{L}}(\boldsymbol{\theta}, \hat{\boldsymbol{\theta}})$ is then increasing until $\hat{\boldsymbol{\theta}}=\boldsymbol{\theta}$, and then decreasing. We then deduce that $\hat{\boldsymbol{\theta}}=\boldsymbol{\theta}$ reaches the global maximum of $\mathbf{U}^{\mathbf{L}}(\boldsymbol{\theta}, \hat{\boldsymbol{\theta}})$.

Thus, thanks to the Spence-Mirrlees condition, the equations (18) and (19) can replace the global incentive constraints. Without this condition, the analysis of the problem of incentives would be more complex. So, we assume that the Spence-Mirrlees condition is checked.

\subsubsection{The Individual Rationality Constraint}

For the individual rationality constraint to be checked, it is necessary that the agricultural lobby receives a utility greater than or equal to its reservation utility, that is to say, it could get the best out of its exchange with the "ICCERGI". The individual rationality constraint expresses that agricultural lobbies accept their contract.

$$
\text { (IR) } \quad \mathbf{U}^{\mathrm{L}}(\boldsymbol{\theta}) \geq 0
$$

The agricultural lobby agrees not to participate in the political game anymore if "ICCERGI" properly defends the economic interests of French farmers by facing the pressure of the contracting parties to the WTO. The agricultural lobby has to see its income increase as it agrees with the "ICCERGI". The increase in income can be done, for example, by distributing subsidies among the French farmers. 


\subsubsection{Maximization of Welfare Expectancy}

The "ICCERGI" must maximize the welfare expectancy of the whole countries under the incentive constraints and participation contract with the condition $B(\theta)$ that is non-decreasing in $\theta$.

$$
\mathbf{W}=[\mathbf{z}(\mathbf{q})-S(\theta)]+\alpha[R(\theta)+S(\theta)-C(\theta)]
$$

To have expectancy, we integrate between $\int_{\underline{\theta}}^{\bar{\theta}}$. The maximization program then becomes:

$$
\operatorname{Max} E(W)=\operatorname{Max} \int_{\underline{\theta}}^{\bar{\theta}}[[z(q)-S(\theta)]+\alpha[R(\theta)+S(\theta)-C(\theta)]]_{\mu}(\theta) d \theta
$$

Under the following constraints:

$$
\begin{gathered}
\text { (IC) } U^{\mathrm{L}}(\boldsymbol{\theta}, \boldsymbol{\theta}) \geq \mathrm{U}^{\mathrm{L}}(\boldsymbol{\theta}, \hat{\theta}) \\
\text { (IR) } \mathrm{U}^{\mathrm{L}}(\boldsymbol{\theta}) \geq 0 \\
\frac{\mathrm{dB}(\boldsymbol{\theta})}{\mathrm{d} \theta} \geq \mathbf{0}
\end{gathered}
$$

$$
\operatorname{Max} E(W)=\operatorname{Max} \int_{\underline{\theta}}^{\bar{\theta}}[\mathrm{z}(\mathbf{q})+(\alpha-1) S(\theta)+\alpha(R(\theta)-C(\theta))] \mu(\theta) d \theta
$$

$\mathbf{z}(\mathbf{q})$ : Gross Consumer Surplus.

$\mathbf{S}(\boldsymbol{\theta})$ : subsidy that depends on the characteristic $\boldsymbol{\theta}$.

$\mathbf{R}(\boldsymbol{\theta})-\mathbf{C}(\boldsymbol{\theta})$ : This is the benefit of French farmers without the help of the state. This is the profit made under free trade.

Determining the function of the welfare of the country is to maximize $\mathbf{E}(\mathbf{W})$ with respect to the function of subsidy.

$$
\frac{\partial E(W)}{\partial S}=(\alpha-1)_{\mu}(\theta)=0
$$

This implies that $\boldsymbol{\alpha}=\mathbf{1}$.

So the "ICCERGI" protects both the economic interests of consumers and farmers. Neither party will have an advantage over the other. Thus, we see that if we can defend the economic interests correctly, we can easily maximize the welfare of the whole country. The balance of economic interests of both parties helps the player in power to be able to make good decisions in international trade negotiations. The WTO is seeking to get this situation because it is consistent with the principles of free trade.

In addition to the incentive constraint of the second order, we can deduce that $\frac{\mathbf{d B}}{\mathbf{d} \boldsymbol{\theta}}(\boldsymbol{\theta}) \geq \mathbf{0}$. The lobbies of characteristic $\theta$ receive a higher budget $\mathbf{B}$ and therefore higher subsidies $\mathbf{S}$.

\subsubsection{Conclusion of the Model}

In this model, we introduced the political interests in international trade negotiations. We demonstrated how the lobby can intervene in the choice of trade policy that the political player must follow: lobbies finance election campaigns of political players in order to obtain the trade policy that defends the economic interests of some people.

This game has allowed us to show the divergence of interests between the political and economic players and more precisely between the player in power and lobbies. The player in power is solely responsible for the commercial policy of the country and for this reason he must be firm in defending the public interest in all 
matters. In contrast, the pressure groups seek only their own interests without considering the interests of the country. We understood that the player in power, who is looking for the interests of the country may take reasonable positions if he is not under pressure from lobby. But the problem is to find someone who can remove the lobbies from the political and economic sphere. This entity which is called the "ICCERGI" must find an incentive mechanism which guarantees to lobbies the protection of their economic interests.

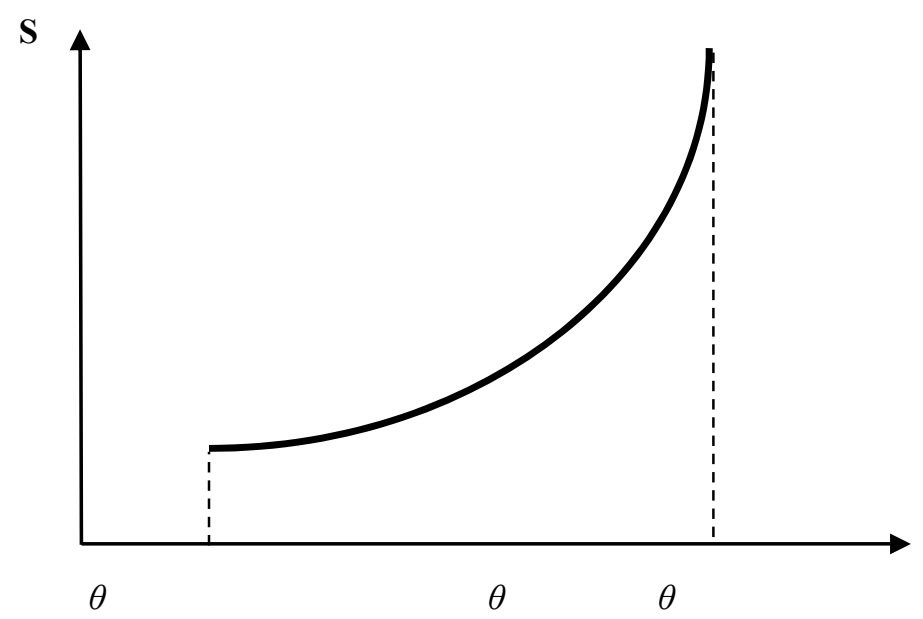

The experience of international trade negotiations of the Uruguay Round showed that the French government chose to assist its farmers despite the threats from Americans. This proves that in general each political player tries to maximize the economic interests of his producers since he is obliged to be grateful to lobbies. The adoption of protectionist trade policies is linked by the agreement between the political players and lobbies. The political stakes are the first responsible for all trade policy, whatever its nature is.

As long as the farm lobby is involved in political game, the "ICCERGI" removes its subsidy. The most rational lobbies leave the political game to increase the protection of their economic interests. So, the lobbies that do not participate in the political game must obtain a positive surplus: it is their informational rent. Lobbies involved in the political game must be punished by imposing sanctions such as the removal of subsidies or payment of fines.

The agricultural lobby cannot leave the political game unless it sees its income rise, that is to say when the "ICCERGI" protects the interests of farmers well. Similarly, the consumers must see their surplus upward either through lowering taxes or through lowering the prices obtained by the reduction of trade barriers. Achieving a balance of economic interests of both parties seems to be the right strategy for maximizing the well-being of the country.

The "ICCERGI" must properly manage the national and international pressure. It should play on both fronts by giving each party what it deserves. The "ICCERGI" should not then elicit aggression from either of the two parties as there is a risk that may lead to violent protests or even on an international trade war. It must ensure that both parties find satisfaction in the resolution of a given commercial problem.

\section{The Other Incentive Mechanisms that We Can Suggest}

The existence of some lapses in the political game obliges us to create some incentive mechanisms. The first thing to do is to give the player in power more time to be able to present his political strategy. Most players in power are not able to complete their projects because the working time is short and there are problems that cannot be resolved in the short term. The second thing we must do is to find an incentive mechanism to avoid giving voters wrong information. Voters should have the information needed to move towards the political player who best responds to their preferences.

\subsection{The Prohibition of Financing Political Parties by Lobbies}

The best mechanism which can make the political game much more transparent is to avoid any agreement that may exist between political players and lobbies. The failure that exists in the political game is that voters are not aware of the tricks that exist between political players and companies. The voter has no accurate information about the true tactics of each political player.

To make the political game more loyal, we need to create a law that prohibits the financing of political parties by 
lobbies or more precisely by the companies. This law should encourage political players to seek the economic and social interests of the whole country. During the election period, the political players had better not cheat by creating an agreement with the companies: the law should exclude or legally pursue the political player who is illegally funded by some companies.

The creation of this law is then an incentive mechanism that seeks to avoid falling into the problems of corruption. The tricks between political players and businesses cause a disruption of the political game because all political players will not have the same chance of being equally funded. That is to say that some political players have much larger financial aids than those granted to other political players. For example, pro-protectionist companies will give maximum financial aid to the political player that ensures tariff protection against foreign products. In contrast, the political player who is in favor of a commercial policy of free trade will not have the same financial assistance that is offered by the pro-protectionist companies.

The financial aids that are offered by companies must be replaced by public assistance. The government should provide the political players with the same financial assistance so that everyone can have the same chance to play in the elections. A part of the taxes paid by companies and citizens to the government must be devoted to the financing of the political players. The control of financial aid of the political player by an independent organism is needed in the political game. The audit should be present in any election period and in any election campaign.

\subsection{Extending the Period of Work of the Player in Power}

The first mechanism which must be created is the one that gives the player in power the necessary time to achieve his political strategy. We noted that the period of work devoted to the player in power is often short and does not allow him to collect the fruit of his policy. In the short term, the elected political player has no time to solve the most serious economic and social problems such as unemployment or social exclusion. In the United States, the period of four years is not enough for the President to achieve the end of his projects.

The short time given to the player in power has a negative impact on the unrolling of international trade negotiations. Trade problems are sometimes negotiated with one president and sometimes with another. We will not have the same commercial policy if the two presidents do not have the same ideology. During the trade negotiations of the Uruguay Round, there were three types of political players who rule France: the beginning of the Uruguay Round, which corresponds to the phase of power sharing (1986-1988), was ruled by the right-wing party. In the midst of this cycle, we saw the socialists who ruled the country. The end of this cycle, which also corresponds to the phase of power sharing, was given back again to the right-wing party. So the team change in government may not be favorable to operate in international trade negotiations. Each team cannot finish its projects. There are always some breaking off.

Thus, the player must remain long enough in power to be able to solve economic and social problems. The most serious problems cannot be solved in the short term. By taking again the example of French politics, we notice that the non-coincidence between the presidential and legislative period is the main cause of the disturbance of the strategies of the player in power. " To rectify this state of affairs, it is necessary to couple the presidential and legislative elections, by adopting the same term of office and the same election date. The likelihood of ideological divergence between the president and the parliamentary majority would be considerably reduced and the decision horizon of power significantly expanded" (Genereux, 1995, p 254).

\subsection{Avoiding Providing Voters with Wrong Information}

The second mechanism to be built is the transmission of information. Indeed, we need to find an incentive mechanism that avoids giving voters wrong information: the manipulation of information is a strategy used by most political players to influence voters. Taking advantage of information to attract voters does not give the true value of the political player. We need deep information about the political players so that voters can vote for the most reliable candidate and who has a good project for the country.

So, the political players must avoid the misleading advertising. Each political player must offer feasible and better quality policy products. Genereux (1995) thinks that " to limit natural duplicity of political speech and discourage the abuse of systematic confidence, could the citizen's right be included in the constitution to honest information about politicians and action of the government? The implementation of this right would require a recourse of citizens to be against political lies; a recourse the sanction of which would be a formal finding by the competent jurisdiction that the power lied" (Genereux 1995, p 262). This law encourages political players to announce the true characteristic of their political strategies. Each political player will change his behavior by trying to be honest towards voters. He does not have to promise a political product which is difficult to achieve. 
We must also find a way that can convey accurate information about the political players. This can be only the media that can distribute the information to all voters. Television news is the primary source of information that can reach all voters. In France, the Superior Audiovisual Council (SAC) must give each political player the chance to present his program for all political players in a definite period of time. This special program for political players is evidence that can be used against those who make false promises.

Political players will have to distrust what they present as a promise and should present a perfect study on the fulfillment of their promises. Each political player must take the threat of punishment seriously if the program fails. The punishment should be severe for political players who exaggerate the promises that are impossible to carry out. This punishment may be temporary or permanent expulsion from the political game. The threat of eviction is an incentive mechanism able to guide the policy players towards finding workable and effective political programs. The political players cannot, at this point, lie or cheat in the political game because they will be judged on the results of their political strategies.

\section{Conclusion}

To conclude, it should be noted that it is only in recent decades that economists have begun to be interested seriously in the impact of political issues on the choice of a trade policy to follow. The adoption of protectionist trade policies is largely related to the involvement of lobbyists in any decision made by the player in power. The lobbies promise to contribute to the campaign of political players in exchange for tariff protection for their industries. So the principle of "give and take" applied between the candidates in the election and the lobbying forces oblige the elected candidate to protect the economic interests of domestic industries by setting tariffs on foreign goods.

The political issues play an important role in determining the trade policy that the government must follow in international trade negotiations. Indeed," politically speaking, a better knowledge of interactions between the economic interests and the political behavior can help to define better institutional rules to favor the international cooperative solutions" (Laussel and Montet, 1994).

Each political player is supposed to be supported by lobbies. All industries which participated in the election campaigns wish their political players were elected. Indeed, the political player protects his industries from international competition, which contributed to his election, by taxing foreign products of interest to these industries, or by following a business policy of subsidy. So these are the industries that supported the elected political player which will be the most favored.

International trade negotiations have been influenced by the intervention of political issues and national interest groups. International trade agreements cannot be reached anymore without considering the lobbies. The player in power is all the time influenced by the opposition players and lobbies when he wants to take a decision on any business problem. The trade negotiations of the Uruguay Round were often disturbed by the pressure of lobbies exerted on the players in power of each country involved in the agricultural conflict.

The policy makers should distrust the commercial issues affecting the sectors with intensive labor force. These problems can disturb the social life of a country and cause a crisis within a modest social class. It is clear, however, that we establish a social imbalance if we conclude a trade agreement contrary to the fundamental interests of a number of citizens. For example, a Multi-fiber Arrangement (MFA) which disfavors the economic interests of developing countries will have a negative impact on labor force known as abundant in this area. The Multi-fiber Arrangement is very important for the developing countries and the least negative decision leads necessarily to an increase in unemployment.

The policymakers must also distrust the new form of pressure that is social media. These latter, which use the new forms of information and communication based on the Internet, have become a new form of serious pressure on policymakers. The millions of tweets, the thousands of article blogs and the numerous videos on YouTube are the drivers of the Arab revolts. Indeed, in recent years, there have been several waves of protests in the"Arab Spring countries" (Tunisia, Egypt, Libya, Yemen, Bahrain and Syria). These national revolutionary movements aim to provide better living conditions especially regarding employment and dignity: the political and social struggles have largely been related to the issue of unemployment. The citizens have the freedom to express and defend their views freely.

The policymakers should now distrust not only the lobby, but also the social media. These latter use more efficient and faster strategies than the lobbies: the information regarding any problem will be gathered through the Facebook, for example, which is a tool for rapid and anonymous mobilization. 


\section{References}

Bardon, P., \& Libaert, T. (2012). Le lobbying. Paris: Dunod.

Bennedsena, M., \& Feldmann, S. E. (2006). Informational lobbying and political contributions. Journal Public Economics, 90(4-5), 634-656.

Bolton, P., \& Dewatripont, M. (2005). Contract Theory. MIT Press.

Brock, W. A., \& Magee, S. (1978). The economics of special interest politics: the case of the tariff. American Economic Review, 68, 246-250.

Brugvin, T. (2009). L'influence des lobbies sur la politique internationale: des actions non démocratiques à l'illégalité, Mondialisation. Ca.

Comité, E. de D. R. (2011). La PAC en mouvement: évolution et perspectives de la Politique Agricole Commune, L'HARMATTAN. Collection Droit et Espace Rural.

Daridan, M-L., \& Luneau, A. (2012). Lobbying: les coulisses de l'influence en démocratie. Collection Village Mondial. France: PEARSON.

Debouzy, O., Clemons, S. C., \& Butt-Philip, A. (2003). Entreprises et politique étrangère. Le Lobbying à Paris, Washington et Bruxelles, Paris.

Feenstra, R. C., \& Bhagwati, J. (1982). Tariff seeking and the efficient tariff. In Bhagwati Import Competition and Response. Chicago: The University of Chicago Press.

Findlay, R., \& Wellisz, S. (1982). Endogeous tariffs, the political economy of trade restrictions and welfare. In Bhagwati Import Competition and Response. Chicago: The University of Chicago Press.

Garault, E., \& Lecerf, G. (2012). Le lobbying, un métier encore en devenir dans une France rétive au dialogue avec la société civile. Revue Géoéconomie, 62. http://dx.doi.org/10.3917/geoec.062.0109

Genereux, J. (1995). Droite, gauche, droite. Librairie PLON Press.

Grossman, E. (2005, November). Lobbying et vie politique, Problèmes politiques et sociaux. La Documentation française, 918.

Grossman, G. M., \& Helpman, E. (1993). Trade wars and trade talks, Working Paper. 4280 NBER.

Groupe, PAC. (2011). Guide de la Politique Agricole Commune, Réalisé par les organisations du groupe PAC.

Guillochon, B. (2006). L'économie politique du protectionnisme. In Berthaud P. \& Kebabdjian G. (eds), La question politique en économie internationale. Coll Recherche, La découverte.

Jensen, M. C., \& Meckling, W. H. (1976). Theory of the firm: Managerial behavior, agency costs and ownership $\begin{array}{lllll}\text { structure. Journal of } & \text { Financial 305-360. }\end{array}$ http://dx.doi.org/10.1016/0304-405X(76)90026-X

Koutroubas, T., \& Lits, M. (2011). Communication politique et lobbying. Bruxelles: De Boeck.

Laffont, J. J., \& Martimort, D. (2002). The theory of incentives: The principal-agent problem. Princeton Univ. Press.

Laffont, J. J. (2006). A propos de l'émergence de la théorie des incitations. Revue Française de Gestion, 32(160), 177-189. http://dx.doi.org/10.3166/rfg.160.177-190

Laussel, D., \& Montet, C. (1994). Les déterminants politiques du protectionnisme: Un aperçu de développements récents. Journées A.F.S.E., 19(20).

Mayer, W. (1993) Lobbying for tariffs policies. Review of International Economics, 1, 221-233. http://dx.doi.org/10.1111/j.1467-9396.1993.tb00018.x

McCarty, N., \& Lawrence, S. R. (1996). Commitment and the campaign contribution contract. American Journal of Political Science, 40(3), 872-904. http://dx.doi.org/10.2307/2111799

Naoi, M., \& Krauss, E. (2009). Who lobbies whom? Special interest politics under alternative electoral systems. American Journal of Political Science, 53(4), 874-892. http://dx.doi.org/10.1111/j.1540-5907.2009.00406.x

Organisation Mondiale du Commerce (OMC). (2007). Comprendre l'OMC, Troisième édition; précédemment publiée sous le titre. Un commerce ouvert sur avenir, Septembre 2003, révisé en février 2007.

Organisation Mondiale du Commerce (OMC). (2012). Statistiques du commerce international, Genève. 
Polère, C. (2007). Lobbying: l'influence des groupes d'intérêts s'accroît, et favorise une transformation de notre modèle démocratique. Millénaire, Le Centre Ressources Prospectives du Grand Lyon.

Reizman, R., \& Wilson, J. D. (1993, August). Politics and trade policy, Working Paper.

Salanié, B. (1994). Théorie des contrats. Economica.

\section{Copyrights}

Copyright for this article is retained by the author(s), with first publication rights granted to the journal.

This is an open-access article distributed under the terms and conditions of the Creative Commons Attribution license (http://creativecommons.org/licenses/by/3.0/). 